\title{
Another Pictish cross-of-arcs: an old find from Shetland re-interpreted
}

\author{
Anna Ritchie ${ }^{1}$
}

\begin{abstract}
A fragment of carved stone known as 'Lerwick' (NMS X.IB.19) is argued to have come, most probably, from the Pictish levels at Jarlshof, Dunrossness, Shetland, sometime before June 1861. The stone bears part of a Pictish crescent symbol on one side and part of a cross-of-arcs embellished with decorated lentoid forms on the other. The symbol-bearing cross-slab from which the fragment comes probably dates to the 7th century and may have stood in or near a churchyard at Jarlshof. It is compared with the cross-slabs from Papil and Bressay and with fragments of similar Shetland stones, and its place in the development of the cross-of-arcs is discussed.
\end{abstract}

In the collections of National Museums Scotland is a small fragment of a Pictish carved stone for which the given provenance is simply 'Lerwick Museum'. This was a museum in the Tolbooth in Lerwick and it belonged to the Shetland Literary and Scientific Society, founded in 1861 to 'promote the formation of a Museum of Natural History and Antiquities', although the title chosen for the new Society presages its ultimately dominant function as a library (Shetland Museum \& Archives, D5/8). Within 20 years the museum had become a burden that the Society sought to shed, and most of its Shetland collection was sold to the National Museum of Antiquities of Scotland and sent to Edinburgh in 1882 (the remainder was sold in Lerwick). The story of museum provision in Shetland has already been explored (Reynolds 2014), and the purpose of this note is to provide more background for this particular fragment and to discuss the form of stone from which it comes. It was among the first 48 donations accepted for the museum on 9 July 1861, listed as no. 11. Sadly only a small part of the original catalogue survives, covering accessions between June 1861 and January 1862 (SMA, D5/8), probably because thereafter there were separate lists for the museum and library, although these are not extant. At the time of the sale in 1882, Alexander Cunningham Hay wrote to John Alexander Smith at the Society of Antiquaries of Scotland: 'We have tried all means to recover the Catalogue of the Museum but without success' (National Museums Scotland Research Centre, NMS SAS UC 85/9, 30 October 1882). Equally unfortunate is the fact that the Shetland Society made no mention in its catalogue of the provenance of artefacts, unless the object came from outwith Shetland, which explains why the carved stone has become known as simply 'Lerwick'. ${ }^{1}$ Smith asked specifically whether any of the artefacts had been found in brochs, but his question appears to have gone unanswered, presumably for lack of information in the records (NMS SAS UC 85/6, 7 October 1882).

Negotiations were underway on the sale of the Lerwick museum collection when Smith, who was one of the honorary Secretaries of the Society of Antiquaries of Scotland, set out on a month-long trip to Orkney and Shetland in August 1882. He had been in touch with John Bruce the Younger, laird of Fair Isle, about collecting artefacts for the National Museum of Antiquities, and on 25 August he was able to join a party that Bruce was taking by steamer to Fair Isle for the day (Smith 1883: 293, 299). He was

${ }^{1}$ anna@anagrams.plus.com 
also able to see the Lerwick museum collection for himself, which proved to be very useful when the sale went through and the artefacts arrived in Edinburgh minus a few items that Smith remembered seeing in Lerwick. There survives a handwritten list of the purchased objects, which is annotated with their monetary values (NMS SAS UC 85/10), from which it seems that the carved fragment was considered to be worth five shillings. A Purchase Committee had been set up by the Council of the Society of Antiquaries of Scotland the previous year with the power to make purchases up to $£ 100$, and a guaranteed minimum price of $£ 50$ was agreed in October 1881 for the Lerwick collection (NMS SAS Minute Book 1880-7). The artefacts were duly sent by steamer from Lerwick to Leith, and members of the Purchase Committee were able to inspect them at their meeting on 4 November, agreeing that more than $£ 50$ would be paid on receipt of the extra items. A final price of $£ 70$ was paid to the Shetland Literary and Scientific Society the following year (Stevenson 1981: 161). A list of artefacts included in the purchase was presented to a meeting of the Society of Antiquaries of Scotland on 11 December 1882, including 'one fragment of a Sculptured Stone with Celtic Ornamentation', but for some reason the carved fragment was not mentioned when the list was published (NMS SAS Minute Book 1880-7; Society of Antiquaries of Scotland 1882-3: 13-20).

\section{DESCRIPTION AND PROVENANCE}

The 'Lerwick' fragment (NMS X.IB.19) is a small portion of a sandstone slab carved on both broad faces, which measures $130 \mathrm{~mm} \times 85 \mathrm{~mm}$ and $35 \mathrm{~mm}$ in thickness and has no intact edge (Scott \& Ritchie 2009: no. 3). It was donated to the museum of the newly founded Shetland Literary and Scientific Society in 1861 by John Bruce of Sumburgh (10th laird, 1798-1885), whose estates included the southern and eastern parts of Dunrossness, as well as much of Sandwick and South Cunningsburgh, in the southern part of the Shetland mainland. While the carved stone could have come from anywhere on the Bruce estates, the likelihood is that it came from Sumburgh itself. The Bruce house at Sumburgh stood close to the ruined laird's house romantically designated 'Jarlshof' by Sir Walter Scott in his novel The Pirate, which crowns a large multiperiod archaeological site which was even then eroding into the sea. Other early medieval carved stones have been found in the Sumburgh area. From the Jarlshof site itself come seven decorated stone discs, including one incised with a double disc and Z-rod symbol, two fragments of a slab incised with a serpent (Scott \& Ritchie 2009: nos 16-19, 23, 25, 27 and 129) (Canmore ID 513 and 514; NGR HU 3982 0955) and a slate fragment incised with a cross, along with numerous other slate graffiti (O'Meadhra 1993: 427-31). The serpent fragments were found on the beach below Jarlshof and are the subject of a study by James Graham-Campbell and Isabel Henderson (forthcoming). Less than $2 \mathrm{~km}$ away to the north-west is another broch site with Pictish and Viking Age levels at Old Scatness, which has also yielded Pictish carved stones (Bond \& Bashford 2010), but here the mound over the site would still have been intact in Bruce's time. Farther north, the burial ground at Mail in South Cunningsburgh has yielded early medieval carved stones in the course of grave digging, but none were recorded prior to 1875 (Canmore ID 72108). The most likely provenance for the carved fragment discussed here, 'Lerwick', is the eroding shoreline of Jarlshof, and the fact that the fragment is not water-worn suggests that it did not lie unnoticed for long. Some 40 years later, Bruce's son, another John Bruce (11th laird, 1837-1907), wrote 'For a long time the mound near the shore, crowned by the ancient Jarlshof, had attracted my attention, more especially as during late years some violent storms tore away now and then a piece from its seaward side and laid bare evidences of built masonry', and excavations began in 1897 (Bruce 1907: 13, fig 1). By this time, coastal erosion had eaten deep into the Iron Age broch and the later wheelhouse settlement beside it. The latter must formerly have extended well to the southwest, and these post-broch levels are likely to have yielded the carved stone under discussion (NGR HU c 3978 0952). Precisely where the 
shoreline lay in 1861 is not known, but the archaeological deposits are likely already to have been exposed.

\section{DISCUSSION OF THE CARVED MOTIFS ON 'LERWICK'}

The fragment bears incised ornament on both faces and may have been part of a doublesided Pictish symbol stone or a symbol-bearing cross-slab (Illus 1). ${ }^{2}$ On face $\mathrm{A}$ is an almost symmetrical design formed of curving lines and double spirals, which may be part of the internal ornament of a Pictish rectangle symbol, many of which contain curvilinear designs. An alternative interpretation as part of a cross-ofarcs is supported by the use of two different depths of cutting, and this is discussed below. On face $\mathrm{C}$ there are the remains of two curvilinear motifs formed of multiple concentric lines, one of which is clearly a double spiral, with an area of cross-hatching above them, which is contained within a curving line. The double spirals are cut more deeply and wider than the cross-hatching, and both show a precise and assured carving technique. This design is likely to be part of a Pictish crescent symbol with internal ornament consisting of double spirals and cross-hatching, and the upper curving line provides the compassdrawn arc for the top of the crescent. In scale the proposed symbols would have been comparable to those on the Breck of Hillwell and Mail slabs in Shetland (Scott \& Ritchie 2009: nos 2 and 5).

At least two other slabs were carved on both sides: the small fragment from the island of Uyea at the south end of Unst and the elaborately ornamented cross-slab from Culbinsburgh in Bressay (Scott \& Ritchie 2009: nos 4 and 54). The Uyea fragment no. 4 has part of a probable rectangle symbol on one side, containing a band of knife-cut lozenges and a row of small spirals, probably arranged in pairs, for which the rectangle symbol on Ackergill 1 in Caithness is a good parallel (Canmore ID 9243). On the other side is part of a large triple spiral formed by three curving lines, cut with a broad flat-bottomed groove, which is $4 \mathrm{~mm}$ deep and widens as the spiral expands. It is similar in size to those in the possible crescent on the 'Lerwick' fragment. ${ }^{3}$ Romilly Allen considered tentatively that both fragments might be parts of symbol stones (Allen \& Anderson 1903, pt 3: 3-5). The use of cross-hatching is unusual, but simple hatching as a filling device can be seen on a number of symbol stones, notably in the crescent symbol
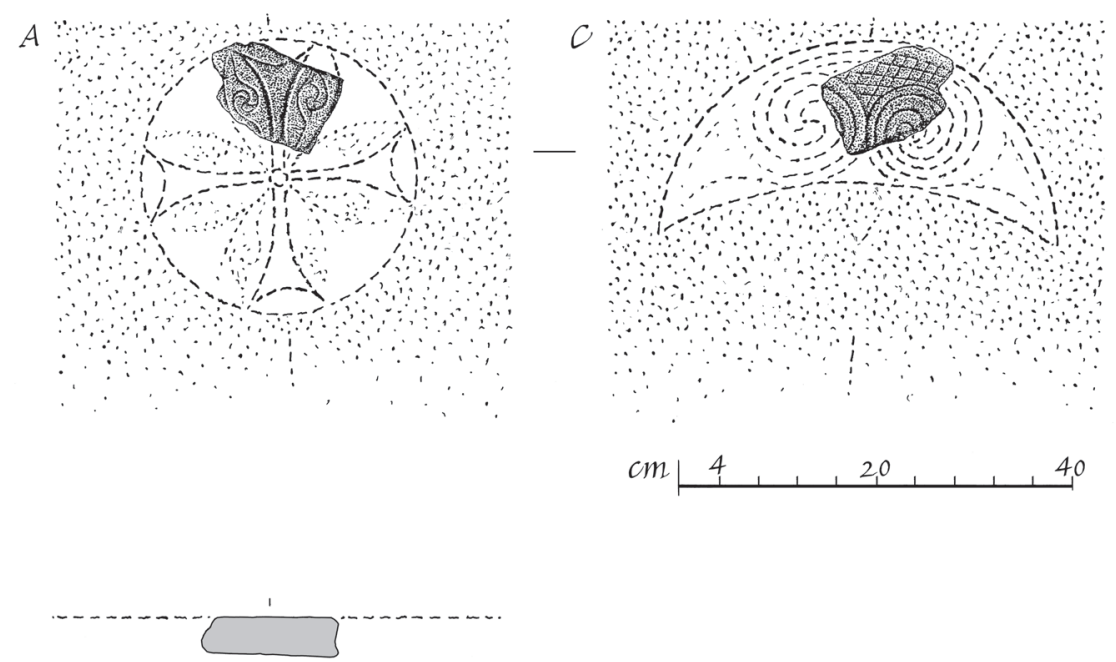

ILLus 1 The carved fragment 'Lerwick' with the proposed reconstruction of face A with a crossof-arcs and face C with a Pictish crescent symbol (C) Ian G Scott; scale 1:10) 
on Breck of Hillwell in Shetland, and in both the crescent and V-rod and rectangle symbols on Clynekirkton 2 in Sutherland (Canmore ID 123604 and 6461). Spirals and hatching are combined in the crescent and V-rod on the Ulbster and Skinnet 1 cross-slabs in Caithness, and hatching fills entirely the background within the crescent on the Lindores symbol stone at Abdie in Fife (Canmore ID 8431, 318992 and 30019). Incised double spirals also appear on one of the stone discs from Jarlshof and on shrine corner posts from St Ninian's Isle (Scott \& Ritchie 2009: nos 16, 31, 34). In addition there is a triple spiral carved in relief on the top of another corner post from St Ninian's Isle (ibid: no. 32), a little smaller than the triple spiral incised on the Uyea fragment. The curvilinear ornament on face A of 'Lerwick' derives ultimately from earlier Iron Age art, probably from the sinuous trumpet coil identified in Morna MacGregor's grammar of ornament (1976: xiv), and the same influence can be seen in the internal decoration of rectangles on the symbol stones Clynekirkton 2, Ackergill 1 in Caithness and in Orkney on Firth and St Peter's, South Ronaldsay (Henderson \& Henderson 2004: 60; Farley \& Hunter 2015: $157,159)$.

Thus the 'Lerwick' fragment may be part of a slab with Pictish symbols on both broad faces, but it is also possible that it belonged to a crossslab and that the proposed crescent is all that survives of face $\mathrm{C}$. The curving lines and double spirals of face A form two lentoid motifs, one on either side of a slender and more deeply incised plain panel with a widely expanded and dished terminal, which may be seen as the arm of a cross (Illus 1). Its position in relation to the crescent on the reverse would make this the upper arm of a cross, and it was most probably contained within a circle. The cross would have had four arms and eight lentoid forms, perhaps with spaces between the pairs of lentoid forms, and probably a small central circle. In size the proposed cross would be very close to that on face A of the Bressay cross-slab, which has very widely expanded arms composed of interlace, separated by four lentoid motifs filled with two-cord knots (Scott \& Ritchie 2009: no. 54). The elaborate crossslab from Papil in West Burra has a plain cross- head with widely expanded arms separated by similarly filled lentoid forms, which form identical pairs, top and bottom (Kilpatrick 2011: 163). The knots in the top two are the same, but the lower two present a mirrored image of one another, and this same mirroring works best in the proposed development of the carving on face A of 'Lerwick', where there would be four pairs of mirrored lentoid forms. The quality of the elegant design of this fragment, as reconstructed, together with specific similarities of decoration suggest that it could have had an influence on the presentation of the ambitious, and clearly related, relief-carved crosses on the Papil and Bressay slabs. ${ }^{4}$ Neither of the latter includes Pictish symbols amongst its decorative repertoire, and the 'Lerwick' slab is likely to have been their precursor.

The overall design of the proposed 'Lerwick' cross may also be linked to the hexafoil or marigold crosses of western Scotland and Ireland, as well as to the more common crossof-arcs, and it illustrates well the 'ambiguity between the cross and its interspaces' discussed by Ian Fisher in connection with these crosses (2001: 12). It is only the deeper carving of the proposed cross-arm that mitigates the ambiguity in the case of 'Lerwick'. There is a particularly close link between the 'Lerwick' cross-of-arcs and that carved below a hexafoil on the east face of Cladh a'Bhile 1 at Ellary in Argyll (Fisher 2001: 141-2). Here the slender arms flare into wide triangular terminals with dished ends as on the 'Lerwick' fragment - and they are separated by four truncated lentoid forms, each of which is incised with a mirrored pair of double spirals, which echo the spirals between the petals of the hexafoil above. The four lentoids in effect combine the eight of the 'Lerwick' cross-of-arcs. Fisher (2001: 141-2) noted the resemblance between this cross-of-arcs at Cladh a'Bhile and that at Reask, Co Kerry, in Ireland, and that resemblance may be extended to Shetland, for the incised shaft of the Reask cross embellished with spirals is comparable to a slate sketch, Jarlshof 9, discussed below. The route of dissemination of such ideas northwards may well have passed through the monastery on Iona, where the great collection of early medieval 
gravemarkers includes a Chi-Rho monogram on a neat slab bearing a 7 th-century inscription and a disc-headed slab with a cross-of-arcs (Iona 22 and 77) (Fisher 2001: 128, 131). Since Ross Trench-Jellicoe published his analysis of the Skeith stone in Fife in 1998, hexafoils and crosses-of-arcs have attracted renewed interest among scholars in Scotland, Ireland and Wales, and a distribution map has been provided by Kelly Kilpatrick in her study of Papil 1 (2011: illus 19). ${ }^{5}$ In Shetland, these distinctive crosstypes appear on metalwork as well as stone monuments, for a true marigold cross appears on the base of bowl 3 in the hoard of Pictish silverwork from St Ninian's Isle, as well as a cross-of-arcs among the multi-cruciform decoration on bowl 1 (Wilson 1973: 47, 50-1; Henderson \& Henderson 2004: 109-10, illus 151 and 156). The recognition of a handsome crossof-arcs on the 'Lerwick' fragment provides another notable example of the prevalence of this design in Shetland. It also supports the view that the cruciform decoration within the circular fields of the double disc and Z-rod on the carved fragment Mail 5 was intended as a reference to the Christian symbol of the cross (Ritchie 2008: illus 1; Scott \& Ritchie 2009: no. 5). Such a reference makes Mail 5 an unusually intimate combination of Pictish symbol and cross, in contrast to the normal practice of placing symbols in the background to the cross.

\section{CHRISTIANITY AT JARLSHOF}

That Christianity was known and practised at Jarlshof at an early date is evident from a small piece of slate bearing an incised graffito cross heavily embellished with spirals, which was found during excavation in the floor levels of a Pictish house (Jarlshof 9) (Hamilton 1956: 88; Scott \& Ritchie 2014: illus 10). O’Meadhra suggested a possible link between this sketched cross and an initial in an early 7th-century manuscript from the monastery at Bobbio in northern Italy. The mention of a Pictish monk, probably an abbot of Bobbio, in another 7thcentury manuscript from the monastery helps to strengthen the link (O'Meadhra 1993: 430-1).
Finely incised crosses may also be found on stone gravemarkers, and George and Isabel Henderson discussed the calligraphic nature of the crosses incised on slabs from Ballachy, Skinnet 2 and Mid Clyth in Caithness (2004: 161-2). Both a lost slab from Papa Stronsay and a fragment from Skaill, Deerness, in Orkney might come under the same heading: the Papa Stronsay cross had pairs of spirals attached to its arm terminals, while on Skaill the cross rises from a domed pedestal and the side-arms appear to have petalshaped extensions (the upper part of the slab is missing) (Scott \& Ritchie 2014: nos 29 and 26). A simpler version of the cross embellished with spirals appears on the shaft of an unusual and relatively sophisticated disc-headed pillar from Kirkton on the island of Great Cumbrae in the Firth of Clyde, where part of a carved lintel hints at its context alongside a church of some distinction (Kirkton 3 and 6) (Fisher 2001: 70-1). This is one of a number of crossslabs in western Scotland which are adorned by hexafoils or crosses-of-arcs (Kilpatrick 2011: illus 19), and Fisher drew attention to the strong Gaulish tradition that lies behind the adoption of these designs here and in Ireland (RCAHMS 1992: 57), citing a manuscript of around AD 700 from the Irish foundation at Luxeuil in eastern France, a sister foundation to Bobbio (Hubert \& Porcher 1969: fig 181). This same line of origin can reasonably be extended northwards via sites such as Cladh a'Bhile in Argyll and the island of Raasay off Skye (Fisher 2001: 103) to Orkney and Shetland, despite the distance and hazardous journeys involved. Adomnán's mention of the northern voyages of Cormac is just one hint of the context in which such ideas spread (Sharpe 1995: chap II, 42), and Shetland's location on the northern edge of the known world would be part of its allure to anchorites and missionaries alike.

At Jarlshof, there is evidence to suggest that there was a medieval collegiate church, dedicated to St Matthew, which was demolished probably when the Old House of Sumburgh (the laird's house) was begun in 1592 (Hamilton 1956: 194-7; Cant 1975: 19), and an early medieval predecessor to this church nearby is quite possible. Sadly all trace of it is probably long gone into the sea, given that the excavations yielded only one 
pre-1592 grave beneath the west gable wall of the house and one fragment of a human skull from a Viking Age midden (Hamilton 1956: 189). Some memory of it survived, for when the churchyard at Quendale was engulfed by sand towards the end of the 18th century the area inside the ruined Old House was utilised for burials (Bruce 1907: 14).

\section{CONCLUSION}

Since the donor of the carved fragment known as 'Lerwick' was John Bruce of Sumburgh, it seems reasonable to associate the stone with the archaeological site of Jarlshof, almost at the southern tip of mainland Shetland. The structural remains at Jarlshof span many centuries, from Neolithic times to the 19th century AD, including an Iron Age broch and a post-broch settlement consisting of wheelhouses and smaller cellular structures, the surviving remains of which are close to the old eroding shoreline, now protected by a sea-wall. There is no doubt that much of the settlement has been lost into the sea (and more may lie unexcavated beneath the later laird's house). It is from these post-broch levels that the serpent stone (Jarlshof 1) and the stone disc carved with a Pictish symbol (Jarlshof 3) came, and, almost certainly, 'Lerwick', a very small fragment of what was originally a fine upstanding monument, carved on both sides. 'Lerwick' may have been a double-sided symbol stone, but it is more likely that it was a symbolbearing cross-slab, with an elegantly designed cross-of-arcs on one side and a crescent symbol on the other (together no doubt with other ornament on the missing part of the slab). The fact that the surviving arm is more deeply incised than its flanking lentoids would suggest that it is more likely to be a cross than part of the internal decoration of a Pictish rectangle symbol. The monument from which the fragment comes may have stood in or near the burial-ground of an early church. The ornament on 'Lerwick' links it to the two most elaborate and intact crossslabs in Shetland, at Papil in West Burra and Culbinsburgh in Bressay, and it joins the list of fragmentary but potentially major monuments in the Shetland corpus, such as those from Uyea, Whiteness and Mail. It dates probably from the 7 th century, based on the elaborate forms of the proposed cross and crescent, and it represents the missionary phase of Christianity that was depicted so graphically on a shrine slab from Papil (Scott \& Ritchie 2009: no. 30). Jarlshof was well placed on the sheltered bay of the West Voe of Sumburgh to be the first landfall in Shetland for monks arriving by curragh from both the west and east coasts of Scotland. It may have been well placed politically too, for Shetland's largest Iron Age fort encompassed nearby Sumburgh Head (Canmore ID 896). Its fortifications survived to impress George Low on his tour of Shetland in 1774 (1879: 185) and are still traceable today, but sadly nothing more is known of what may well have become a royal stronghold in Pictish times. It may never be possible to prove that the 'Lerwick' fragment came from Jarlshof itself, but this does not detract from its interest as an accomplished carving, nor from its importance as evidence of Christianity in the 7 th century in southern Shetland.

\section{ACKNOWLEDGEMENTS}

I am grateful to Yvonne Reynolds, Blair Bruce and Jenny Murray, all of Shetland Museum and Archives, for their help with archival material, and to Martin Goldberg and Jim Wilson of National Museums Scotland for enabling me to re-examine the 'Lerwick' and Uyea fragments. Very special thanks are offered to Isabel Henderson, James Graham-Campbell and Brian Smith for their invaluable comments after reading a draft of this paper and for encouraging me to develop it further - any mistakes in this version are mine. Ian G Scott was kind enough to embellish his original drawing of the 'Lerwick Museum' fragment with my proposed reconstructions, and I am very grateful to John Borland for preparing the drawing for publication.

\section{NOTES}

1 In Scott \& Ritchie 2009, a decorated disc, no. 28 , was attributed to the collection from Lerwick Museum, but it appears that it was a later purchase 
by NMAS in 1898 (BG.151) and came from the Bigton area of Dunrossness.

2 It has not been possible to include an adequate photograph of this fragment.

3 The Uyea fragment (NMS X.IB.18) was presented to the Society of Antiquaries of Scotland in April 1868 by Thomas Irvine of Midbrake in Yell, and it was 'said to have been found in the Island of Uyea, forming the cover to an urn containing burnt bones' (Society of Antiquaries of Scotland 1868: 425; Scott \& Ritchie 2009: no. 4). It was found sometime prior to 1854 when James $\mathrm{T}$ Irvine drew it at Midbrake (Ritchie 2011: 26). There are steatite urns from Uyea in National Museums Scotland, but it has proved impossible to find any link with the carved fragment (Martin Goldberg pers comm). Nonetheless it is clear that the fragment had been reused to seal a cremation burial in an urn, and as such it is reminiscent of the lost symbol stone from Oxtro in Orkney, which formed a cover slab for a short cist containing burnt bones (Scott \& Ritchie 2014: 173, 175, no. 4). Both instances point to early medieval use of cremation and reuse of symbol stones, and in the case of the Uyea fragment to reuse of a stone which had carved ornament on both broad faces. In comparison with the 'Lerwick' fragment, the Uyea fragment is markedly thinner at $25 \mathrm{~mm}$ and, despite the similarly designed spirals, the two are unlikely to have derived from the same slab. The exact find spot of the Uyea fragment and its urn is unknown, but there is a ruinous chapel and graveyard with cruciform grave-markers at the south-east end of the island, together with records of cairns nearby (Canmore ID 1416).

4 This suggestion does not detract from Ross Trench-Jellicoe's argument about the development of crosses incorporating ornamented lentoid forms at Kilduncan in Fife, Papil and Bressay, proposing a derivation from a Hiberno-Norse metalwork model present in the North Sea province (2005: 515-23). In Shetland, an earlier local version in stone may have been strengthened a century or so later by such a metalwork model as he suggests. Kelly Kilpatrick has also emphasised ecclesiastical connections between Shetland and Fife (Kilpatrick 2011: 198).

5 Recent studies include Kilduncan 1, Fife (Trench-Jellicoe 2005), Capel Colman 1 and similar stones in south-west Wales (Edwards 2007), Carndonagh in Co Donegal (Newman \&
Walsh 2007) and a lost stone from Tullich in Aberdeenshire (Geddes et al 2015).

\section{DOCUMENTARY SOURCES}

\section{National Museums Scotland, Edinburgh}

Society of Antiquaries of Scotland Internal Manuscripts, UC 85 Transfer of Shetland Museum artefacts to Edinburgh 1882 (NMS SAS):

UC 85/6: 7 October 1882, draft of letter from J A Smith.

UC 85/9: 30 October 1882, letter from A Cunningham Hay.

UC 85/10: nd, list of artefacts.

Society of Antiquaries of Scotland, Minute Book 1880-7.

Shetland Museum \& Archives (SMA)

D5/8: Lerwick Museum and Library record of donations.

\section{REFERENCES}

Allen, J R \& Anderson, J 1903 The Early Christian Monuments of Scotland. Edinburgh: Society of Antiquaries of Scotland.

Bond, J M \& Bashford, D J 2010 'Carved and incised stone', in Dockrill, S J, Bond, J M, Turner, V E, Brown, L D, Bashford, D J, Cussans, J E \& Nicholson, R A Excavations at Old Scatness, Shetland, vol 1: The Pictish village and Viking-Age settlement, 304-20. Lerwick: Shetland Heritage Publications.

Bruce, J 1907 'Notice of the excavation of a broch at Jarlshof, Shetland', Proc Soc Antiq Scot 41: 11-33.

Cant, R G 1975 The medieval churches and chapels of Shetland. Lerwick: Shetland Archaeological $\&$ Historical Society.

Edwards, N 2007 'Early medieval sculpture in south-west Wales: the Irish Sea connection', in Moss (ed.), 184-97.

Farley, J \& Hunter, F (eds) 2015 Celts: art and identity. London: The British Museum/ National Museums Scotland.

Fisher, I 2001 Early Medieval Sculpture in the West Highlands and Islands. Edinburgh: RCAHMS/Society of Antiquaries of Scotland. 
Geddes, J, Murray, H K \& Murray, J C 2015 'Tullich, Aberdeenshire', Proc Soc Antiq Scot 145: 229-81.

Graham-Campbell, J \& Henderson, I, with Ritchie, A \& Scott, I G forthcoming 'A Pictish "serpent" incised slab from Jarlshof, Shetland', in Smith, B (ed.) The St Ninian's Isle Treasure Sixty Years On. Lerwick: Shetland Heritage Publications.

Hamilton, J R C 1956 Excavations at Jarlshof, Shetland. Edinburgh: HMSO.

Henderson, G \& Henderson, I 2004 The Art of the Picts: sculpture and metalwork in early medieval Scotland. London: Thames \& Hudson.

Hubert, J \& Porcher, J 1969 Europe in the Dark Ages. London: Thames \& Hudson.

Kilpatrick, K A 2011 'The iconography of the Papil Stone: sculptural and literary comparisons with a Pictish motif', Proc Soc Antiq Scot 141: 159-205.

Low, G 1879 A tour through the islands of Orkney and Schetland. Reprinted 1978, Inverness: Melven Press.

Lowe, E A 1948 Codices Latini Antiquiores: a palaeographical guide to Latin manuscripts prior to the ninth century, vol 3, Italy: AnconaNovara. Oxford: Clarendon Press.

MacGregor, M 1976 Early Celtic Art in North Britain. Leicester: Leicester University Press.

Moss, R (ed.) 2007 Making and Meaning in Insular Art. Dublin: Four Courts Press.

Newman, C \& Walsh, N 2007 'Iconographical analysis of the Marigold Stone, Carndonagh, Inishowen, Co Donegal', in Moss (ed.), 16783.

O’Meadhra, U 1993 'Viking-Age sketches and motif-pieces from the northern Earldoms', in Batey, C E, Jesch, J \& Morris, C D The Viking Age in Caithness, Orkney and the North Atlantic, 423-40. Edinburgh: Edinburgh University Press.

RCAHMS 1992 Argyll: an inventory of the monuments, vol 7, Mid Argyll \& Cowal. Edinburgh: HMSO.
Reynolds, Y 2014 'A passion to preserve: a history of museum provision in Shetland', unpublished MLitt dissertation, University of St Andrews.

Ritchie, A 2008 'A fragment of a Pictish symbolbearing slab with carving in relief from Mail, Cunningsburgh, Shetland,' Proc Soc Antiq Scot 138: 185-92.

Ritchie, A 2011 A Shetland Antiquarian: James Thomas Irvine of Yell. Lerwick: Shetland Amenity Trust.

Scott, I G \& Ritchie, A 2009 Pictish and VikingAge Carvings from Shetland. Edinburgh: RCAHMS.

Scott, I G \& Ritchie, A 2014 'Pictish symbol stones and early cross-slabs from Orkney', Proc Soc Antiq Scot 144: 169-204.

Sharpe, R 1995 Adomnán of Iona: Life of St Columba. London: Penguin.

Smith, J A 1883 'Notes on some stone implements, \&c, from Shetland, now presented to the Museum', Proc Soc Antiq Scot 17: 291-9.

Society of Antiquaries of Scotland 1866-8 'Donations to the Museum', Proc Soc Antiq Scot 7: 422-6.

Society of Antiquaries of Scotland 1882-3 'Anniversary Meeting, 30th November 1882', Proc Soc Antiq Scot 17: 1-21.

Stevenson, R B K 1981 'The museum, its beginnings and its development, Part II: the National Museum to 1954', in Bell, A S (ed.) The Scottish Antiquarian Tradition: essays to mark the bicentenary of the Society of Antiquaries of Scotland and its museum, 1780-1980, 142-211. Edinburgh: John Donald Publishers Ltd.

Trench-Jellicoe, R 1998 'The Skeith Stone, Upper Kilrenny, Fife, in its context', Proc Soc Antiq Scot 128: 495-513.

Trench-Jellicoe, R 2005 'A richly decorated crossslab from Kilduncan House, Fife: description and analysis', Proc Soc Antiq Scot 135: 50559.

Wilson, D 1973 'The treasure', in Small, A, Thomas, C \& Wilson, D M St Ninian's Isle and its Treasure, 45-148. Oxford: Oxford University Press. 